\title{
Adaptation options under climate change for multifunctional agriculture: a simulation study for western Switzerland
}

\author{
Tommy Klein • Annelie Holzkämper • \\ Pierluigi Calanca $\cdot$ Jürg Fuhrer
}

Received: 15 October 2012/ Accepted: 29 April 2013/Published online: 25 May 2013

(C) Springer-Verlag Berlin Heidelberg 2013

\begin{abstract}
Besides its primary role in producing food and fiber, agriculture also has relevant effects on several other functions, such as management of renewable natural resources. Climate change (CC) may lead to new trade-offs between agricultural functions or aggravate existing ones, but suitable agricultural management may maintain or even improve the ability of agroecosystems to supply these functions. Hence, it is necessary to identify relevant drivers (e.g., cropping practices, local conditions) and their interactions, and how they affect agricultural functions in a changing climate. The goal of this study was to use a modeling framework to analyze the sensitivity of indicators of three important agricultural functions, namely crop yield (food and fiber production function), soil erosion (soil conservation function), and nutrient leaching (clean water provision function), to a wide range of agricultural practices for current and future climate conditions. In a twostep approach, cropping practices that explain high proportions of variance of the different indicators were first identified by an analysis of variance-based sensitivity analysis. Then, most suitable combinations of practices to achieve best performance with respect to each indicator were extracted, and trade-offs were analyzed. The procedure was applied to a region in western Switzerland, considering two different soil types to test the importance of local environmental constraints. Results show that the sensitivity of crop yield and soil erosion due to
\end{abstract}

T. Klein $(\square) \cdot$ A. Holzkämper · P. Calanca · J. Fuhrer Air Pollution/Climate Group, Agroscope Research Station ART, Reckenholzstrasse 191, 8046 Zurich, Switzerland e-mail: tommy.klein@alumni.ulg.ac.be

T. Klein · A. Holzkämper · P. Calanca · J. Fuhrer Oeschger Center for Climate Change Research, University of Bern, Bern, Switzerland management is high, while nutrient leaching mostly depends on soil type. We found that the influence of most agricultural practices does not change significantly with $\mathrm{CC}$; only irrigation becomes more relevant as a consequence of decreasing summer rainfall. Trade-offs were identified when focusing on best performances of each indicator separately, and these were amplified under CC. For adaptation to $\mathrm{CC}$ in the selected study region, conservation soil management and the use of cropped grasslands appear to be the most suitable options to avoid tradeoffs.

Keywords Multifunctional agriculture - Climate change adaptation $\cdot$ CropSyst $\cdot$ Trade-offs

\section{Introduction}

Agriculture is among the economic sectors that are most sensitive to climate change (CC). In Europe, the combination of increased air temperature and changes in the amount and distribution of precipitation could cause significant shifts in agroclimatic zones (Trnka et al. 2011). More frequent droughts and extreme weather events during the cropping season are likely to increase the number of unfavorable years, which may cause enhanced yield instability and make current agricultural areas less suitable for traditional crops (Olesen and Bindi 2002), with differential CC impacts depending on crops and regions (Supit et al. 2012).

In Switzerland, projections for 2050 indicate a temperature increase ranging from +1.5 to $+3.5^{\circ} \mathrm{C}$, with precipitation changes ranging from -15 to $+15 \%$ in winter and from -5 to $-25 \%$ in summer relative to $1980-2009$ (CH2011 2011). An increase in air temperature in 
combination with a marked shift in the seasonality of precipitation may increase drought risk on the Swiss Central Plateau (Calanca 2007; Fuhrer et al. 2006). Such changes are likely to have negative impacts on agricultural productivity and to significantly increase production risks toward the end of the century (Fuhrer et al. 2006; Torriani et al. 2007). Hence, adaptations of cropping practices, such as changes in crop choice or irrigation, seem unavoidable in order to reduce the vulnerability of crop production to CC.

Besides its primary role in producing food and fiber, agriculture also has relevant effects on several other functions, such as the management of renewable natural resources, landscape, conservation of biodiversity, and contribution to the socioeconomic viability of rural areas (UNCED 1992). The concept of multifunctionality of agriculture has attracted many scientific contributions from different disciplines (Renting et al. 2009) and led to the development of a wide range of modeling approaches (Rossing et al. 2007) with a special focus on trade-offs between multiple objectives (see, e.g., Groot et al. 2007). Improved understanding of how local conditions (e.g., soil, weather) and cropping practices affect yield variability and cause environmental impacts is necessary to support policy-making in favor of multifunctional agriculture (Nelson et al. 2009). However, generalization is difficult as impacts may vary substantially among regions and could be altered by CC. Moreover, it is known that adaptation strategies for improving crop yield may aggravate existing harmful impacts on the environment or lead to novel negative impacts (Schröter et al. 2005).

Ecophysiological models are widely used to examine options for adaptation by stakeholders and policy-makers as they have the ability to explore large sets of agricultural practices. White et al. (2011) reported that most of the previous studies focused on one crop in combination with a limited number of agricultural practices. Typically, only one cropping practice is tested, sometimes two, but rarely more than three. To the latter category belongs the study by Ruane et al. (2013) who investigated the effect of season length, planting date, fallow period, soil type, cultivar choice and fertilizer use on maize growth in Panama. They found that planting date and soil type are important drivers of maize yield. Planting date and use of cultivar with a longer/shorter growth cycle were the most frequently varied options in the literature. For Swiss crops, Torriani et al. (2007) found that early sowing and use of crops with longer growth cycle greatly reduce negative impacts of CC, particularly in grain maize, and Moriondo et al. (2010) showed that expanding the growth cycle is an efficient adaptation strategy to reduce vulnerability to $\mathrm{CC}$ in sunflower, soybean, and spring/winter wheat. Also, use of irrigation substantially increased crop yields in areas where rain-fed production is possible under current conditions.
Only few studies examined nutrient fertilization, tillage practices and crop rotations as adaptation options. Van Ittersum et al. (2003) showed that some effects of CC, for instance decreases in grain nitrogen $(\mathrm{N})$ content, could be offset by extra N fertilization. Scholz et al. (2008) showed that reduced tillage could contribute to reduced erosion under CC. Changing crop rotations has almost never been tested as adaptation option, mainly due to (a) the lack of empirical data for a proper representation of crop rotations (Schönhart et al. 2011) and (b) the fact that models need to be calibrated specifically for every crop involved in the rotation. Nevertheless, Ko et al. (2011) simulated impacts of projected CC on the productivity of dryland crop rotations of wheat-fallow, wheat-corn-fallow, and wheatcorn-millet and found high yield differences between crop rotations.

In general, modeling studies exploring effects of $\mathrm{CC}$ and potential for adaptation focus on impacts on economic yield (White et al. 2011), neglecting other functions. However, exceptions can be found in the literature. This is, for example, the case of Van Ittersum et al. (2003) who assessed impacts of $\mathrm{CC}$ and agricultural practices on numerous variables connected to biomass and $\mathrm{N}$ allocation. Agricultural functions (a) food and fiber production, (b) soil conservation, and (c) clean water provision were found to be strongly affected by $\mathrm{CC}$ in previous studies (Bindi and Olesen 2010; Nearing et al. 2004; Olesen and Bindi 2002) and are of major importance in the context of adaptation in Switzerland (FOEN 2012).

In this study, we selected three indicators in order to quantify main aspects of those functions: crop yield for food and fiber production, soil erosion for soil conservation, and nutrient leaching for clean water provision. The aim of this study was to investigate the sensitivity of those indicators to a wide range of agricultural practices under current and future climate conditions based on a simulation model. We address specifically three main questions:

1. How do the indicators respond to agricultural practices and to $\mathrm{CC}$ ?

2. Which combinations of agricultural practices provide the greatest potential for adaptation to $\mathrm{CC}$ ?

3. What trade-offs result from different adaptation options?

In a two-step approach, cropping practices that have largest impacts on the indicators were first identified by a sensitivity analysis based on the quantification of the proportion of total variance explained by every practice. Then, combinations of practices to achieve best performance with respect to each indicator were extracted. The analysis was conducted for an agricultural area located in the western part of the Swiss Plateau that already suffers from water shortage (Fuhrer and Jasper 2012). Two contrasting soil 
types that are representative of the study region were investigated to account for the effect of local environmental constraints, and two contrasting CC scenarios were used in order to account for uncertainties in climate projection.

\section{Methods}

\section{Crop model}

\section{Model description}

An integrated process-based model was used, which allows for simulating a wide range of agricultural practices. CropSyst (version 4.13.04) was selected for three reasons: (1) It does simulate not only agricultural yield but also soil erosion and N-leaching; (2) it covers most of agricultural practices currently in use in the study region; and (3) it is a generic crop model and has been successfully applied to test adaptation in similar contexts (e.g., Moriondo et al. 2010; Torriani et al. 2007).

In CropSyst, biomass accumulation is calculated as a function of crop potential transpiration and intercepted radiation. Potential growth is corrected by factors reflecting water and $\mathrm{N}$ limitations to compute actual daily biomass gain. The final crop yield is the total biomass accumulation over the growing season multiplied by a harvest index.

Soil loss due to water erosion is calculated using the "revised universal soil loss equation" (RUSLE, Renard et al. 1997), which expresses average annual erosion expected on field slopes as the product of six factors. The first factor is the rainfall energy intensity, which accounts for the erosive power of rain. The second one is the soil erodibility factor, which accounts for the influence of soil properties on soil loss during storm events. Then, two factors are used to integrate the effect of slope (length and steepness). A factor for soil conservation practice is also used, and finally, the C-factor represents the effect of land management on erosion, which depends on surface residue cover, incorporated residues, crop cover, and soil moisture.

The components of the simulated $\mathrm{N}$ balance include $\mathrm{N}$ transport, $\mathrm{N}$ transformations, ammonium sorption, and crop N uptake (Stöckle et al. 1994). N-leaching is determined on the basis of a so-called bypass coefficient as proposed by Corwin et al. (1991). The bypass coefficient simplistically accounts for flow through cracks and macropores that bypasses small and dead-end pores, the flow of a mobile water phase independent of an immobile phase of water, and the phenomenon of dispersiondiffusion. $\mathrm{N}$ transformations considered in CropSyst include net mineralization, nitrification, and denitrification. They are assumed to take place in the first $30-50 \mathrm{~cm}$ of the soil profile and are simulated by first-order kinetics (Stöckle and Campbell 1989). Ammonium in the soil is either absorbed into the soil in solid phase or dissolved in soil water. A Langmuir relationship is used to relate ammonium in solution to ammonium in the soil matrix. Crop $\mathrm{N}$ uptake is computed as the minimum between crop $\mathrm{N}$ demand and potential $\mathrm{N}$ uptake. Crop $\mathrm{N}$ demand is the amount of $\mathrm{N}$ the crop needs to meet its potential growth, plus the difference between the crop maximum $\mathrm{N}$ concentration and the actual $\mathrm{N}$ concentration. Potential $\mathrm{N}$ uptake is a function of the maximum $\mathrm{N}$ uptake per unit length of root, root length, $\mathrm{N}$ availability, and soil moisture.

\section{Model setup and testing}

CropSyst was calibrated for the seven main crops in Switzerland, that is, winter wheat, winter barley, grain/ silage maize, potato, sugar beet, winter rapeseed using the calibration procedure developed by Klein et al. (2012). As grass is the primary type of livestock feed in Switzerland covering $71 \%$ of the total agricultural surface (BFS 2004) and is frequently cultivated in rotations, CropSyst was also calibrated for grassland using data from an experimental site located on the Swiss Central Plateau near Oensingen $\left(7^{\circ} 44^{\prime} \mathrm{E}, 47^{\circ} 17^{\prime} \mathrm{N}, 450 \mathrm{~m}\right.$ a.s.l.) (Ammann et al. 2009). In this experiment, the field was typically cut 4 times/year and was fertilized with solid ammonium nitrate or liquid cattle manure after each cut. Soil had clay content between 42 and $44 \%$, total pore volume of $55 \%$, and water volume of $32 \%$ at the permanent wilting point. The calibration of CropSyst for grassland was developed as follows: Firstly, crop parameters were adjusted so that simulated grass biomass accumulation, leaf area index (LAI), and evapotranspiration were in line with observations. Secondly, soil parameters (e.g., saturated hydraulic conductivity) were tuned to further improve the match between observed and simulated soil moisture at various depths. Legume fraction-which is a critical parameter to compute atmospheric $\mathrm{N}$ fixation-was set to 0.3 , representing the mean observed value. After calibration, the model was able to reproduce very well total annual harvested biomass $\left(r^{2}\right.$ of 0.89$)$, leaf area index ( $r^{2}$ of 0.6$)$, actual crop transpiration $\left(r^{2}\right.$ of 0.70$)$, and soil water content $\left(r^{2}\right.$ of 0.81 for soil moisture at $30 \mathrm{~cm}$ ).

RUSLE is the most commonly used soil erosion model worldwide, and it owes its popularity to its minimal data, calibration, and computation requirements as well as to its transparent and robust model structure (Prasuhn et al. 2013). Following Arnold and Williams (1989), CropSyst computes rain erosive power based on daily rainfall and a monthly factor $\alpha_{m}$ expressing the average fraction of daily rainfall that can occur during a 30 -min period as a 
maximum. $\alpha_{m}$ was calculated from 30-min rainfall data for the period 1981-2010 and assumed to be stable under CC. The latter assumption is supported by an analysis of the relation between peak-hourly intensity and daily total amounts, as simulated by the climate scenarios. We assumed a typical slope steepness of $10 \%$ and a slope length of $100 \mathrm{~m}$. A soil conservation practice factor of 0.88 was used, which is a representative value for croplands in Switzerland (Prasuhn et al. 2007). Validation of soil loss predictions through soil erosion models is generally difficult (Gobin et al. 2004). Prasuhn et al. (2013) attempted to validate their high-resolution soil erosion risk map of Switzerland based on RUSLE with 10-year field data for 203 plots in the Swiss Plateau and found a good congruence between modeled and observed soil loss. Simulated erosion by CropSyst after calibration compared relatively well to empirical data from Prasuhn (2012) that were collected in western Switzerland. Simulated erosion was 6.3/ $1.3 \mathrm{t} \mathrm{ha}^{-1}$ year $^{-1}$ with regular tillage/no till and retention of harvest residues, while soil losses measured on experiment sites were $3.4 / 0.75 \mathrm{t} \mathrm{ha}^{-1}$ year $^{-1}$ on plow-tilled fields/on fields with $1 \%$ of mulch-tilled land with more than $30 \%$ surface residue cover. Despite the fact that RUSLE tends to overestimate observed soil loss values, which has been often pointed out (Bartsch et al. 2002; Evans 2002), the ratio between erosion with regular till and erosion with no till as simulated by the model is very similar to the observations.

Empirical data on fluxes and stocks of $\mathrm{N}$ are scarce for Switzerland, which makes the calibration and assessment of models complicated (Dueri et al. 2007). For this reason, CropSyst could not be specifically calibrated with regard to N-leaching. Nevertheless, we tested the plausibility of N-leaching simulations by comparing them with results from a lysometer experiment by Nievergelt (2002) in NE Switzerland. After calibration, CropSyst simulated mean N-leaching values of around $30 / 27.5 \mathrm{~kg} \mathrm{~N} \mathrm{ha}^{1}$ year $^{1}$, while mean values of $47.6 / 39.5 \mathrm{~kg} \mathrm{~N} \mathrm{ha}^{-1}$ year $^{-1}$ with optimum/ reduced fertilization were measured at the experimental site. The fact that simulated N-leaching values are lower than those observed in field experiments could be a consequence of different choices of rotations or different soil types.

\section{Sensitivity analysis}

To quantify the relative importance of each agricultural practice for productivity, soil erosion, and N-leaching, simulation outputs were subject to a factorial decomposition of the model response variability (analysis of variance, ANOVA). Simulations were performed following a complete factorial design. The ANOVA-based sensitivity method is computed as follows: $\mathrm{SS}_{T}=\sum_{i} \mathrm{SS}_{i}+\sum_{i<j}$ $\mathrm{SS}_{i j}$, where $\mathrm{SS}_{i}$ is the main effect contribution of each practice to the overall outcome variance $\left(\mathrm{SS}_{T}\right)$, and $\mathrm{SS}_{i j}$ the interactions between factors. Decomposition of model response was limited to two-factor interactions since the highest sensitivities are most often associated with loworder interactions (Ginot et al. 2006). The total sensitivity index for a given factor was calculated as the sum of main and interactive effects.

\section{Case study}

\section{Study region}

The study region is the area located around the weather station of Payerne in the western part of the Swiss Central Plateau. In this region, irrigation is already applied regularly for some crops (e.g., potato or sugar beet). Soil information was derived from the Soil Suitability map of Switzerland (BFS 2012) and adjusted with soil profile information from the Swiss Soil Monitoring Network (BUWAL 2003). The two most common soil types in this region were considered:

- Sandy loam soil characterized by a rather coarse texture with $65 \%$ sand, $25 \%$ silt, and $10 \%$ clay;

- Loamy soil characterized by a finer texture with $40 \%$ sand, $40 \%$ silt, and $20 \%$ clay.

Observed weather data were obtained from the monitoring network of the Swiss Federal Office of Meteorology and Climatology (MeteoSwiss). The stochastic weather generator LARS-WG (Semenov and Barrow 1997) was used to generate 25 years of synthetic daily weather data for (a) a baseline period corresponding to 1981-2010 and (b) two climate scenarios for the time horizon 2036-2065 that span a significant portion of the full range of changes in temperature and precipitation projected by the ensemble of regional climate model simulations carried out in the framework of the ENSEMBLES project (van der Linden and Mitchell 2009) under the assumption of the A1B emission pathway. The first scenario refers to a run performed with ETHZ-CLM (ETH) and is characterized by a strong $\mathrm{CC}$ signal in summer $\left(+3.5{ }^{\circ} \mathrm{C}\right.$ and $-24 \%$ in seasonal precipitation amount); the second scenario refers to a run performed with the SMHIRCA-HadCM3Q3 (SMHI) and suggests more moderate changes for summer season $\left(+1.3^{\circ} \mathrm{C}\right.$ and $-11 \%$ in seasonal precipitation amount), but an important increase in seasonal precipitation amount during fall $(+21 \%)$. Both climate scenarios agree on small changes in precipitation intensity during spring, summer, and fall, but a significant intensity increase $(\sim+20 \%)$ 
during winter. Seasonal changes in terms of temperature, precipitation amount, and precipitation intensity for both climate scenarios can be found in the "Appendix" (Table 2).

\section{Experimental plan}

A complete factorial experimental plan was set up consisting of four agricultural practices: irrigation (two levels), management intensity with regard to $\mathrm{N}$ fertilization and grassland clippings (three levels), soil management (use of tillage and residue management, two levels), and crop rotation choice (selection of cultivars and sequence, 50 levels). Each set of practices was tested for three different weather datasets (baseline climate and two climate scenarios) and two soil types, resulting in a total of $2 \times 3 \times 2 \times 50 \times 3 \times 2=3,600$ runs. Detailed information on crop-specific values used in the experimental design for each practice and level is listed in the "Appendix" (Table 3).

\section{Irrigation}

Two irrigation options were included in the experimental plan: rain-fed and supplemental (automatic). Automatic irrigation is triggered when soil moisture falls under a certain crop-specific threshold. Then, soil moisture is refilled until a user-defined level. Parameter values for automatic irrigation (minimum soil moisture and refill point) were determined based on economic considerations following Lehmann et al. (2013), who found that irrigation is only profitable for potato, sugar beet, and grain maize under present and future climate (based on both ETH and SMHI).

\section{Crop rotation}

Crop rotations affect the performance of cropping systems with respect to both productivity (e.g., effects on water/ nutrient balance or pests and diseases) and environmental impacts (nutrient leaching or erosion). Hence, it was crucial to include crop rotation choice as a potential adaptation strategy. As a possible way to circumvent the lack of empirical data, a rotation generator can be used to create realistic crop sequences based on expert knowledge (see, e.g., Bachinger and Zander 2007; Dogliotti et al. 2003; Schönhart et al. 2011). Here, a simple crop rotation generator was developed in order to stochastically simulate 5 -year rotations. These were constrained with regard to (a) the feasibility of crop sequences and (b) maximum crop shares as recommended by Vullioud (2005). It was assumed that cropped grassland could only be grown for two consecutive years. Following Swiss legislations for subsidies, a cover crop had to be included unless the current crop was harvested after August 31, and/or the following crop was a winter crop.

Fifty different crop rotations were generated based on the eight crops for which CropSyst was calibrated (Table 4). Rotations characterized by identical crop mixes differing only in terms of sequence were removed-new ones were generated instead-in order to maximize the variability in crop mixes. Conditional sowing dates were used for each crop within the rotation. In practice, the earliest possible sowing date was prescribed, but sowing event could be postponed until a crop-specific temperature threshold was reached. Threshold values that are representative for regional conditions were provided by expert judgment. Crop harvest was set to occur right after physical maturity, or 5 days before sowing the next crop if maturity was not reached on time.

\section{Management intensity}

Management intensity was related to (a) the total amount of $\mathrm{N}$ fertilizer and (b) the number of grassland clippings. Three intensity levels were tested: high intensity (recommended $\mathrm{N}$ fertilization, 5 clippings), medium intensity (recommended $\mathrm{N}$ fertilization $-25 \%, 4$ clippings), and low intensity (recommended $\mathrm{N}$ fertilization $-50 \%$, 3 clippings). Recommended $\mathrm{N}$ fertilization was derived from Flisch et al. (2009), while application dates depended on total $\mathrm{N}$ applied following Janssen et al. (2009).

\section{Soil management}

Two types of soil management were investigated: conventional (regular tillage and removal of residues) and conservation management (no tillage and residues retained). Tillage consisted of plowing 10 days prior to sowing and harrowing 1 day before sowing. When residues were removed, a biomass loss coefficient of $10 \%$ was used (recommended value in CropSyst).

\section{Model application}

\section{Initial conditions}

Initial soil moisture was set to field capacity. A value of 12 $\mathrm{kg} \mathrm{N} \mathrm{ha}^{-1}\left(\mathrm{NO}_{3}-\mathrm{N}+\mathrm{NH}_{4}-\mathrm{N}\right)$ was assumed for the initial soil mineral $\mathrm{N}$ content in the top $30 \mathrm{~cm}$ (Weisskopf et al. 2001). Initial values for organic $\mathrm{N}$ were obtained from a 300-year model spin-up. This was necessary to adjust the 
stable fraction of organic matter. Regular tillage was assumed for the spin-up. At equilibrium, CropSyst simulated an organic matter content of $2.9 \%$ for the first soil layer and $2 \%$ for other layers. Ranges of observations in the study area are [2.5, $5 \%]$ for top layer and $[0.5,2 \%]$ for deeper layers (Leifeld et al. 2003).

\section{Processing of model outputs}

To account for climate variability, 5-year rotations were repeated 5 times for a total of 25 years. Outputs of interest (crop yield, soil loss, and N-leaching) were then averaged for every crop in the rotation, based on those five replicates.

Because crop types differ in potential yield level, ranging from about $2.3 \mathrm{t} \mathrm{ha}^{-1}$ of dry matter for winter rapeseed to about $16.5 \mathrm{t} \mathrm{ha}^{-1}$ for sugar beet, agricultural productivity of a rotation was defined as the arithmetic mean of individual crop yields scaled according to $\tilde{Y}=$ $\frac{Y-Y_{\min }}{Y_{\max }-Y_{\min }}$, where $Y_{\min }$ and $Y_{\max }$ are the crop-specific minimum/maximum yield values obtained under current climate across all soil types.

Yearly average values of productivity, erosion, and $\mathrm{N}$-leaching for each set of practices were computed as the arithmetic mean of individual values reached by different crops in the rotation. These average values were then used to conduct the sensitivity analysis and to determine the most suitable adaptation strategies to achieve best performances with respect to the different indicators.

\section{Results}

Variability in model outputs

Variability in model outputs for scaled productivity, erosion, and N-leaching across the large number of cropping practices is summarized in Fig. 1. Variability in productivity across all agricultural practices is high, with an interquartile range of about 0.2 under current climate and slightly lower under CC $(\sim 0.15)$. Many extreme values and outliers occur in both directions (i.e., high and low productivity). Median agricultural productivity is higher on loamy soil, which is characterized by higher water retention potential. However, maximum productivity of 0.91 (i.e., $91 \%$ of maximum possible yield on average over the rotation) is reached for sandy loam soil. Median yield slightly decreases under $\mathrm{CC}$ on both soil types, particularly for simulations based on the ETH climate scenario $(\sim-10 \%)$.

Also, variability in soil loss is high. Erosion is much higher $(\sim+50 \%)$ and more variable for loamy soil compared to sandy soil. Moreover, extreme values occur more
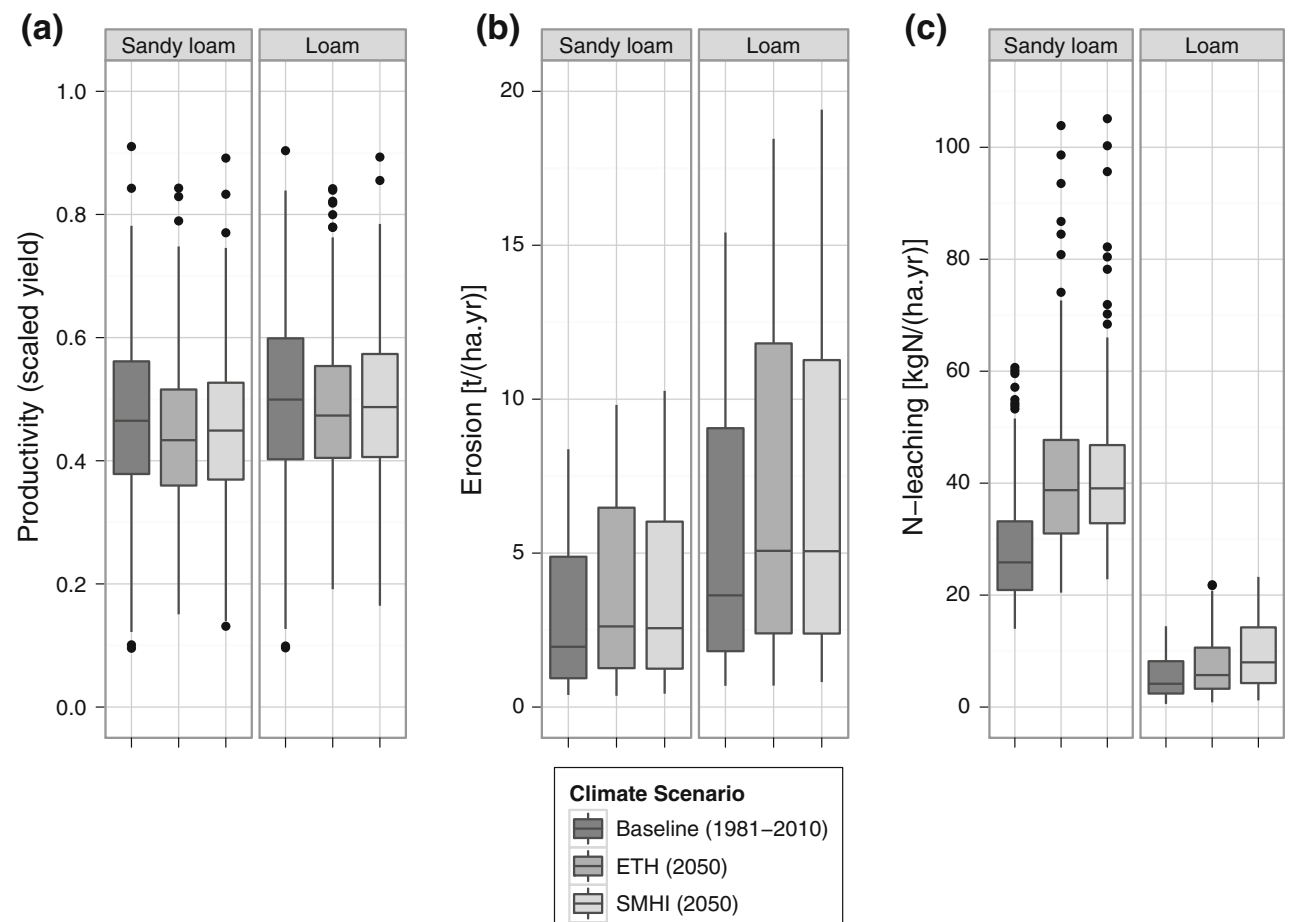

Fig. 1 Variability due to agricultural practices for two soil types, two climate scenarios for 2050 (ETH-CLM and SMHIRCA-HadCM3Q3) and a baseline (1981-2010). a Agricultural productivity (average scaled yield over rotation); b soil erosion; c N-leaching 
frequently, but no outliers are found. For both climate scenarios, variability in simulated erosion slightly increases under $\mathrm{CC}$, and the median of soil loss increases, in particular on loamy soil $(\sim+35 \%$ under $\mathrm{CC})$. The trend toward increased erosion under $\mathrm{CC}$ is attributed to shorter growing cycles with more frequently uncovered soil in fall/ winter, coinciding with increased precipitation intensity during this period of the year (Table 2).

In contrast to productivity and soil erosion, variability in $\mathrm{N}$-leaching across different sets of practices is very small. Indeed, simulated N-leaching is mostly driven by soil type, with high values on sandy loam soil and low values on loamy soil. In general, N-leaching increases under $\mathrm{CC}$ due to enhanced organic matter mineralization as a consequence of higher temperatures, with sometimes values exceeding $100 \mathrm{~kg} \mathrm{~N}^{-1}$ year $^{-1}$ on sandy loam soil.

\section{ANOVA-based sensitivity analysis}

Figure 2 presents the sensitivity of simulation outputs to agricultural practices split between direct and interactive effects. Main effects of rotation, intensity, and soil management account for almost $100 \%$ of total variance of productivity simulations for all climate scenarios. A strong correlation between productivity of rotation and total $\mathrm{N}$ uptake, ranging from 0.73 to 0.79 depending on soil type and climate scenario, suggests that nutrient management is critically important to maintain productivity. An important proportion of available $\mathrm{N}$ for plants comes from organic matter mineralization, which is also influenced by crop management. A lower $\mathrm{C} / \mathrm{N}$ ratio of dead material (i.e., straw and root residues) resulting from high $\mathrm{N}$ uptake enhances residue mineralization. A positive correlation between mineralization and root biomass (0.27-0.36) suggests that large root biomass allows for higher $\mathrm{N}$ uptake and more dead material to be mineralized. Mineralization rate is highly dependent on soil management, for example, removal of crop residues after harvesting increases soil temperature, which consequently accelerates mineralization. Under CC, irrigation becomes more relevant $(10 \%$ of variance with ETH compared to $\sim 0 \%$ under present climate). Rotation further gains in importance under $\mathrm{CC}$, while the relevance of intensity remains stable. Soil management explains a lower fraction of variance under $\mathrm{CC}$ because higher temperatures lead to higher mineralization rates and increase $\mathrm{N}$ availability and, hence, reduce the effect of soil management on soil temperature. Very similar results are obtained with both soil types, except that irrigation is slightly more important on the coarser soil with lower water retention capacity.

Results indicate that soil management is and will be the most important driver of erosion, with nearly $70 \%$ of variance explained. Soil management has a direct effect on soil permeability and runoff, which affect in turn soil loss. Another important factor is the rotation choice (main effect $\sim 10 \%$ variance). No significant differences can be found between soil types.

Variability in N-leaching due to management is comparatively low, and crop rotation choice explains almost $100 \%$ of the total variance. Our results exhibit high correlations $(>0.5)$ between $\mathrm{N}$-leaching and the number of days of fallow (not shown), suggesting that, in order to reduce leaching, it is essential to maintain $\mathrm{N}$ soil content at minimum and to ensure regular $\mathrm{N}$ uptake even during autumn/early winter with the establishment of a winter crop or a cover crop. $\mathrm{N}$ fertilization has low impact on N-leaching, probably because maximum applied fertilizer amounts were set to recommended levels. In general, all factors other than crop rotation are somewhat more important on the coarser soil, but remain substantially less important than crop rotation. Moreover, relevance of irrigation slightly increases under CC for sandy loam soil. The same trend is observed for soil management, particularly in simulations based on SMHI.

Interactions play an important role especially with regard to agricultural productivity and erosion, but are less important than main effects (Fig. 2). Most of interactions are found to be statistically significant at the $p \leq 0.001$ level and of the same magnitude on different soil types (Tables 5, 6 in "Appendix"). Highest interactions are obtained involving crop rotation with other agricultural practices, with soil management in particular. For instance, soil management type has little effect on productivity after grassland (not shown); the latter is an excellent pre-crop to increase soil organic matter and provides $\mathrm{N}$ through $\mathrm{N}$ fixation by clover. In contrast, grain maize cultivation as a pre-crop depletes soil $\mathrm{N}$, which results in low yield levels for following crops in the rotation unless high fertilization and/or conventional soil management are applied. Effects of soil management and crop rotation on erosion are not additive and highly interdependent. Indeed, the crop rotation determines the time when the soil is exposed to erosion, while soil management determines the daily soil loss rates because of small aggregates (tillage) and soil protection (residues). Interactions between crop rotation and intensity have to do with the fact that some crops are more dependent on additional mineral $\mathrm{N}$ applications (e.g., winter rapeseed) than others which can extract more available soil $\mathrm{N}$ with deep rooting systems (e.g., maize). Interactions between the crop rotation and irrigation level are obvious as only a subset of crops are irrigated.

Most suitable agricultural practices

Table 1 lists the combinations of practices for achieving best performances in terms of: (a) agricultural 


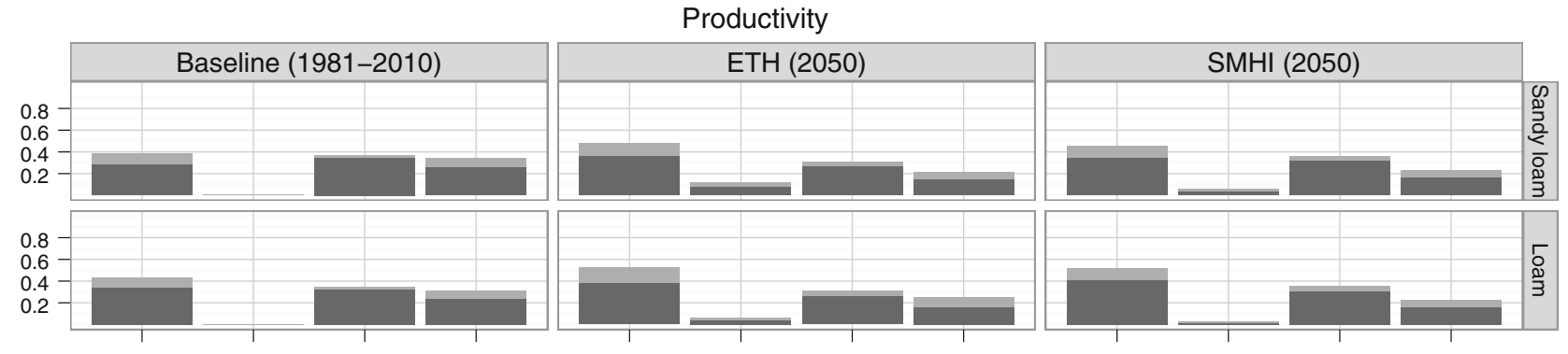

Erosion
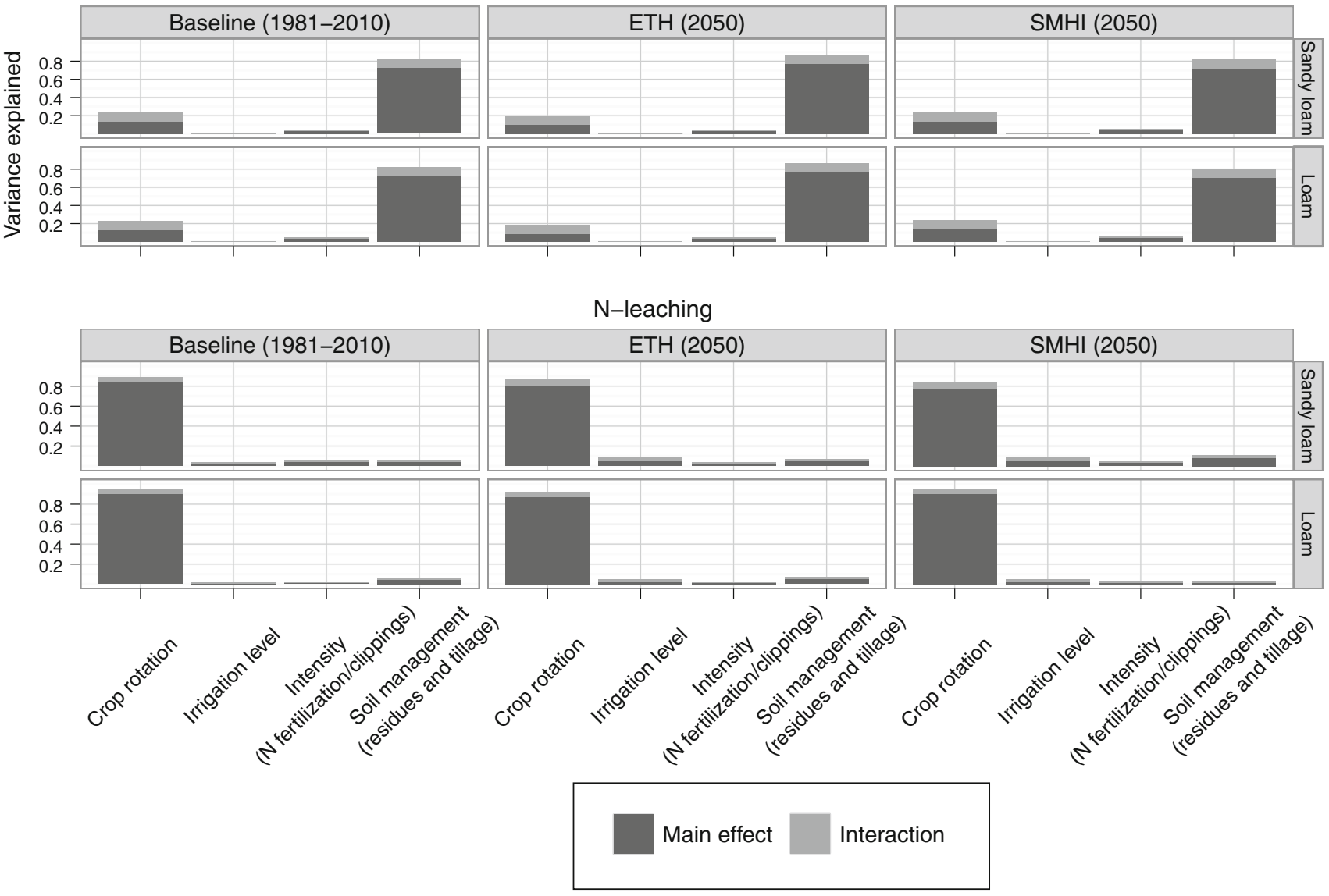

Fig. 2 Results of an ANOVA-based sensitivity analysis to agricultural practices of CropSyst outputs for productivity, soil erosion, and $\mathrm{N}$-leaching

productivity, (b) erosion, and (c) N-leaching. In the following, only results for practices explaining more than $25 \%$ of variability (see Fig. 2) are described. Highest productivity is reached by highly fertilizing the crop rotation with sugar beet-silage maize-winter barleymaize-winter wheat and with conventional soil management. Note that highest productivity is reached with identical set of practices, irrespective of soil type and climate scenario. Even though effect of irrigation on productivity averaged for the rotation is generally low, it contributes to increase yield under CC for this particular set of practices, especially in the case of sandy loam soil where productivity increases by 48 and $52 \%$ with irrigation for SMHI and ETH, respectively, as compared to the same set of practices without irrigation. As expected, irrigation amount increases substantially under CC (Table 1).

Conservation soil management, that is, low soil disturbance and retaining of residues after harvest, leads to lowest soil loss rates. The use of cropped grasslands within rotations is also beneficial to reduce soil loss, although the effect is small compared to that of soil management, probably because only two years of grasslands were included in the experimental plan. 
Table 1 Most suitable agricultural practices for: (a) maximum productivity, (b) minimum soil erosion, and (c) minimum N-leaching

\begin{tabular}{|c|c|c|c|c|}
\hline CC scenario & Crop rotation & $\begin{array}{l}\text { Irrigation } \\
\left(\mathrm{m}^{3} \mathrm{ha}^{-1} \text { year }^{-1}\right)\end{array}$ & $\begin{array}{l}\text { Intensity } \\
\left(\mathrm{kg} \mathrm{N} \mathrm{ha}^{-1} \text { year }^{-1}\right)\end{array}$ & Soil management \\
\hline \multicolumn{5}{|l|}{ Loam soil } \\
\hline \multicolumn{5}{|c|}{ Maximum productivity } \\
\hline Baseline & SB SMAI WB c MAI WW $\mathrm{c}^{\mathrm{a}}$ & 988 & $136^{\mathrm{a}}$ & Conventional $^{\mathrm{a}}$ \\
\hline ETH & SB SMAI WB c MAI WW $\mathrm{c}^{\mathrm{b}}$ & 1,415 & $136^{\mathrm{a}}$ & Conventional \\
\hline SMHI & SB SMAI WB c MAI WW $c^{b}$ & 1,190 & $136^{\mathrm{a}}$ & Conventional \\
\hline \multicolumn{5}{|c|}{ Minimum soil erosion } \\
\hline Baseline & WW GRASS GRASS WW c SMAI & 0 & $188 / 5$ cuts & Conservation $^{\mathrm{c}}$ \\
\hline ETH & WR GRASS GRASS SB WW & 577 & $186 / 5$ cuts & Conservation $^{\mathrm{c}}$ \\
\hline SMHI & WR GRASS GRASS SB WW & 360 & $186 / 5$ cuts & Conservation $^{\mathrm{c}}$ \\
\hline \multicolumn{5}{|c|}{ Minimum N-leaching } \\
\hline Baseline & WR c MAI WW c MAI WW ${ }^{c}$ & 452 & 71 & Conventional \\
\hline ETH & WR c MAI WW c MAI WW & 865 & 64 & Conventional \\
\hline SMHI & WR c MAI WW c MAI WW ${ }^{c}$ & 637 & 64 & Conventional \\
\hline \multicolumn{5}{|c|}{ Sandy loam soil } \\
\hline \multicolumn{5}{|c|}{ Maximum productivity } \\
\hline Baseline & SB SMAI WB c MAI WW $c^{a}$ & 986 & $136^{*}$ & Conventional $^{\mathrm{a}}$ \\
\hline ETH & SB SMAI WB c MAI WW ca & 1,383 & $136^{\mathrm{a}}$ & Conventional \\
\hline SMHI & SB SMAI WB c MAI WW $c^{a}$ & 1,213 & $136^{\mathrm{a}}$ & Conventional $^{\mathrm{a}}$ \\
\hline \multicolumn{5}{|c|}{ Minimum soil erosion } \\
\hline Baseline & WW GRASS GRASS WW c SMAI & 0 & $188 / 5$ cuts & Conservation $^{c}$ \\
\hline ETH & WR GRASS GRASS SB WW & 568 & $186 / 5$ cuts & Conservation $^{\mathrm{c}}$ \\
\hline SMHI & WW GRASS GRASS WW c SMAI & 0 & $188 / 5$ cuts & Conservation $^{\mathrm{c}}$ \\
\hline \multicolumn{5}{|c|}{ Minimum N-leaching } \\
\hline Baseline & SB MAI POT c MAI WW $c^{c}$ & 831 & 58 & Conventional \\
\hline ETH & WR c SMAI POT c SMAI WB ${ }^{c}$ & 811 & 70 & Conservation \\
\hline SMHI & SB MAI POT c MAI WW $c^{c}$ & 901 & 58 & Conventional \\
\hline
\end{tabular}

$W W$ winter wheat, $W B$ winter barley, MAI grain maize, SMAI silage maize, POT potato, SB sugar beet, WR winter rapeseed, GRASS cropped grassland, $c$ winter cover crop

${ }^{\text {a }} 0.25 \geq$ variance explained $<0.50$

b $0.50 \geq$ variance explained $<0.75$

c $0.75 \geq$ variance explained

Regarding N-leaching, results differ strongly between soil types. On loamy soil, the most suitable crop rotation contains high proportions of winter wheat and maize (winter rapeseed-maize-winter wheat-maize-winter wheat). On sandy loam, the most suitable crop rotation also contains two years of maize, but a lower proportion of winter wheat and a higher proportion of other crops (e.g., potato).

\section{Trade-offs}

To explore possible trade-offs between production and environmental impacts, we compare estimates of productivity, erosion, and N-leaching for the most suitable agricultural practices presented above. Results in Fig. 3 reveal a strong trade-off between production and erosion $/ \mathrm{N}$ leaching. Suitable cropping practices for obtaining lowest erosion and lowest $\mathrm{N}$-leaching are generally associated with medium or low productivity. Conversely, high productivity can be achieved only at the expense of high environmental impacts. While results of the ANOVAbased sensitivity analysis are similar for the two soil types, the extent of these trade-offs differs between soil types. Erosion is significantly higher on loamy soil because of higher runoff, while leaching is substantially higher on sandy loam soil due to higher infiltration, but similar yield levels are reached on both soil types.

High productivity (about $90 \%$ of maximum possible yield) can be maintained under $\mathrm{CC}$, but trade-offs with environmental impacts increase (see max productivity scenario on Fig. 3). On sandy loam soil, erosion increases by $45 / 38 \%$, while N-leaching increases by $77 / 85 \%$ under ETH/SMHI. On loamy soil, erosion under baseline is 

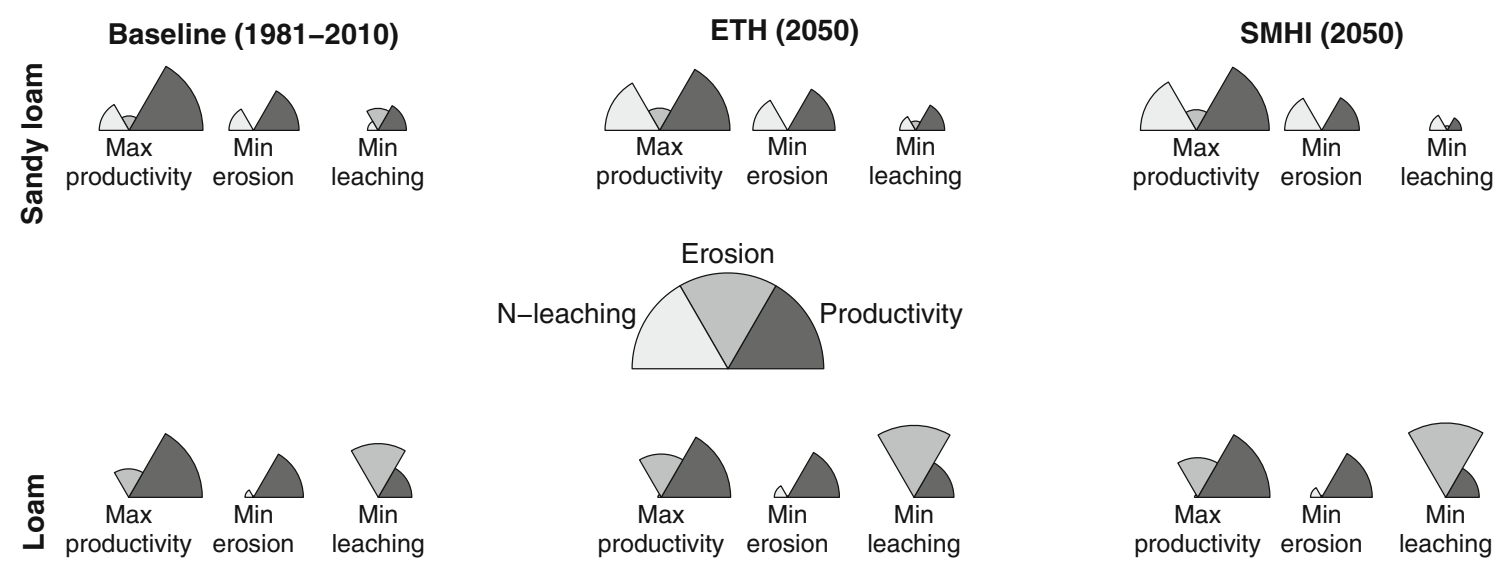

Fig. 3 Trade-offs reached under the most suitable adaptation strategies (Table 1) to achieve best performance with respect to different indicators

approximately twice as high as on sandy loam soil and further increases under $\mathrm{CC}$ with similar rates as on sandy loam soil, while N-leaching is low under present climate and remains low under $\mathrm{CC}$.

Low erosion rate (see min erosion scenario on Fig. 3) can be maintained under $\mathrm{CC}$, but $\mathrm{N}$-leaching increases by $37 / 49 \%$ and is accompanied by medium productivity of $60 / 55 \%$ of maximum possible yield with ETH/SMHI on all soil types.

Low N-leaching values (see min N-leaching scenario on Fig. 3) increase under CC, by $46 / 63 \%$ (sandy loam) and 49/110 \% (loam) with ETH/SMHI. Management for lowest $\mathrm{N}$-leaching values leads to erosion decrease by $120 / 165 \%$ for ETH/SMHI on sandy loam soil. Conversely, on loamy soil, erosion increases moderately, by $25 / 30 \%$ for ETH/ SMHI. The set of practices to achieve lowest N-leaching leads to very low agricultural productivity, ranging from 17 $\%$ (sandy loam SMHI) to $48 \%$ (loam ETH) of maximum possible yield.

\section{Discussion}

Impacts of CC, adaptation, and trade-offs

Sustainable management of cropping systems aims to reach high productivity while at the same time maintaining other functions such as soil conservation and clean water provision. Simulation results in this study reveal the specific sensitivity of indicators of these functions to agricultural practices, local soil conditions, and $\mathrm{CC}$, and possible tradeoffs between individual indicators under current and future climatic conditions. Such information can help in designing multifunctional adaptation measures. It is well known that changes in specific farming practices may mitigate crop losses under CC (IPCC 2007), but by considering multiple functions and practices, the present analysis goes beyond earlier studies that addressed only individual adaptive measures.

According to our simulations, a wide range of crop yield levels can be reached, depending on the combination of crop rotation, soil management, and intensity. Cropping practices identified in the sensitivity analysis all affect nutrient availability, in particular the choice of crop rotations and associated fallow periods between successive crops. The present simulations suggest that practices that maintain high soil temperature and sufficient humidity, such as heavily fertilized rotations involving crops such as sugar beet in combination with conventional soil management, that is, soil tillage and residue removal, enable high mineralization and nitrification rates and are in the short term beneficial for productivity.

With a changing climate, namely higher temperature and drier conditions during the growing season (CH2011 2011), median yield level and yield variability were simulated to decline in the study area. Results suggest that a loss of productivity can be reduced by adapting rotation, soil management, and fertilization. We found that the choice of suitable rotations is even more important in the future than under current climate because crop-growing season length becomes shorter and the potential for negative impacts of $\mathrm{CC}$ on productivity increases. The slight decrease in variability is at first sight opposite to findings from previous studies (see, e.g., Torriani et al. 2007). However, the latter referred only to single crops and did not account for compensating effects within a rotation cycle.

Overall, the combination of practices that can sustain high productivity in the future was found to be the same as under current climate. The main difference is given by the fact that irrigation becomes an important option to cope 
with higher soil moisture deficits under CC. Note that even though the effect of irrigation on productivity averaged for the rotation is generally low-partly due to the fact that not all the crops were irrigated-effects are highly positive for some crops. Irrigation is slightly more important on the coarser soil because of its lower water retention capacity.

A trend toward increased erosion under CC has often been modeled (Nearing et al. 2005; Yang et al. 2003) because of the intensification of the hydrological cycle, which entails increased rainfall amounts and storm intensity (Nearing et al. 2004). The increase in soil erosion under CC disclosed by our simulations is overall more moderate than found by Michael et al. (2005) for Saxony. Apart from differences in the $\mathrm{CC}$ scenarios, this likely reflects the fact that most suitable management practices identified in our analysis include a cover crop during winter (see "Crop rotation" section). In our simulations soil preservation was found to be favored by soil conservation practices. Leaving crop residues in the field increases soil surface protection and reduces runoff (Scholz et al. 2008). Choice of crop rotation has a small effect on soil loss, but the results suggest benefits of an increased share of cropped grasslands and the exclusion of potato. This is in line with the finding by Jones et al. (2003) that soil erosion is expected to be highest with root crops in Central Europe because ground and canopy cover are low during the time of seedbed preparation and in the first weeks of vegetative development, and because this period coincides with the time of the year with highest amount of erosive rainfall.

If heavy precipitation occurs during periods of high soil $\mathrm{N}$ availability, then the risk of $\mathrm{N}$-losses in groundwater is particularly high (Weisskopf et al. 2001). Our results suggest that N-leaching is primarily dependent on soil texture and not much on management, in agreement with field observations by Askegaard et al. (2011). The inclusion of a winter crop or a cover crop in the rotation proved to be particularly beneficial to maintain $\mathrm{N}$ uptake during periods of high mineral $\mathrm{N}$ availability in autumn and early winter. The importance of cover crop to reduce $\mathrm{N}$-leaching has been widely suggested in the literature, based on either modeling studies (e.g., Constantin et al. 2012; Doltra et al. 2011; Henke et al. 2008) or field experiments (e.g., Askegaard et al. 2011; Doltra et al. 2011; Weisskopf et al. 2001).

Agricultural functions are interdependent, and typically, a trade-off exists between food production and regulating functions (Power 2010). Therefore, the choice of adaptation measures that only consider food and fiber production while ignoring concurrent effects of management on the environment does, as a rule, not conform to the objectives of a multifunctional agriculture. Our simulations reveal that maintaining high productivity is indeed associated with poor soil conservation and clean water provision, and these trade-offs appear to be more important under CC than under present climate (Fig. 3). Negative impacts of practices associated with high productivity on soil and water quality were found to depend on soil type, with loamy soil being more sensitive to erosion because of lower infiltration rate and higher runoff, while sandy loam being more prone to high $\mathrm{N}$-leaching and thus water pollution.

Trade-offs may exist also depending on timescale. For instance, we found positive effect of residue removal on productivity. Apparently, this is in contrast to the view that management decisions such as no till and returning crop residue to the field increase soil organic matter content, improve infiltration and soil water retention, and thus help to maintain soil fertility in the long run and increase the resilience of cropping systems to CC (Lal et al. 2011). However, the positive effect of conventional soil management simulated here is short-lived; by repeating simulations under $\mathrm{CC}$ using 50 years of generated weather data, we found a significant decrease in soil fertility that is not evident in the original results (not shown).

Apart from preventing excessive soil erosion and soil organic matter loss and thus maintaining soil fertility in the long run, we found that conservation soil management improves clean water provision. Indeed, simulated N-leaching is substantially decreased on sandy loam soil due to reduced mineralization, while the increase in permeability due to this management type has low effect on this soil type which is already permeable. As a downside, productivity was found to be lowered by $\sim 50 \%$ on average under current climatic conditions under conservation soil management. However, under CC this effect is less pronounced $(\sim-25 \%)$, indicating that the synergistic effects of conservation soil management could increase in the future.

Trade-offs between agricultural productivity and other ecosystem functions are not inevitable, though (Power 2010), and in fact possible synergies between the different agricultural functions emerge from our analysis. As soil management and crop rotation are the most relevant practices to reduce soil loss and N-leaching, respectively (Fig. 2), and also exert a great influence on productivity, a balance between productivity and environmental impacts may be obtained from a judicious choice of crops and soil cultivation. In our analysis, best compromises are obtained with management practices that minimize soil loss (Fig. 3).

Our results suggest that for the study area rotations including a grass/legume crop are very important to support multifunctional agriculture. In fact, grassland serves well as a good pre-crop, and a high proportion of grassland reduces erosion and helps keeping N-leaching at low levels. Soil $\mathrm{N}$ benefits from grass/clover mixture while grain maize cultivation as a pre-crop depletes soil $\mathrm{N}$, which results in low yield levels for following crops in the 
rotation, unless high fertilization and enhanced mineralization compensate for the $\mathrm{N}$ loss.

Sensitivity analysis

We applied an ANOVA-based sensitivity analysis to quantify the relative importance of different agricultural practices for productivity, soil erosion, and N-leaching. ANOVA is based on the decomposition of the response variability between contributions from each factor and from interactions between factors and is an efficient investigation tool that provides ease of interpretation comparable to that of regression methods (Ginot et al. 2006). In crop modeling, ANOVA-based sensitivity analysis is commonly used to screen a subset of model parameters to be calibrated (see, e.g., Confalonieri 2010; Monod et al. 2006).

Assumptions for the application of ANOVA include nullity of the residual expectation, homogeneity of the residual variance, and normality of residual effects. To respect those assumptions and ensure that effects are linear, a transformation of model outputs is usually envisaged (Saltelli et al. 2007). In our study, residuals were small without transformation and nearly $100 \%$ of the variance could be explained by including only first-order interactions (see Tables 5, 6), in spite of the fact that nearly all interactions were statistically significant. This suggests that effects of cropping practices are mostly additive. Similar conclusions were drawn in previous studies addressing similar contexts (Lamboni et al. 2009; Monod et al. 2006).

While N-leaching is almost only sensitive to changes in crop rotation and erosion almost only sensitive to changes in soil management and crop rotation, productivity was found to be sensitive to all driving factors (crop rotation, irrigation levels, intensity, and soil management). This highlights again the fact that crop rotation and soil management are the two aspects of agricultural practice that should be examined to identify best practices for multifunctional agriculture.

\section{Limitations and uncertainties}

The effects of high temperatures, increased climate variability, and limiting factors such as pests and diseases are neither fully understood nor well implemented in leading crop models (Soussana et al. 2010; Rötter et al. 2011). There is also an ongoing debate concerning how well crop responses to elevated $\mathrm{CO}_{2}$ are represented in models (Parry et al. 2004; Long et al. 2006; Körner et al. 2007). For this reason, $\mathrm{CO}_{2}$ fertilization effect was not taken into account in this study.

Future adaptation options will include changes both in agricultural practices and in varieties/species. In this study, we solely focused on the first type of adaptation, mainly due to the difficulty in integrating new crop varieties within crop rotations which were generated for current climate. However, switching to cultivars that are better suited to higher temperatures is crucial (Horie 1994), and this type of adaptation is already taking place under present climate conditions (Sacks and Kucharik 2011). Furthermore, we expect that adoption of new cultivars could help avoiding some of the trade-offs discussed in this study, for example, by reducing the fallow time which would decrease erosion and N-leaching. Nevertheless, skepticism toward the use of these "climate proof" cultivars has been recently observed among the scientific community (Olesen et al. 2011).

From a modeling perspective, the simplest method to account for higher temperatures consists in modifying the thermal time requirements of different phenological stages, in order to mimic slower maturing cultivars that could be obtained through genetic improvement (Duvick 2005). A few examples of modeling studies have implemented this approach (see, e.g., Challinor et al. 2007; Moriondo et al. 2010). This generally resulted in higher simulated crop yields, but without necessarily improving yield stability (Torriani et al. 2007). However, addressing thermal time requirements of different crops in crop rotation has yet to be addressed in modeling studies, and future work should investigate the potentialities offered by newly developed varieties to define sets of crop sequences that are better suited under CC.

\section{Conclusions}

The sensitivity of indicators of three important agricultural functions (crop yield for food and fiber production, soil erosion for soil conservation, and nutrient leaching for clean water provision) to agricultural practices was assessed for current and future climate conditions in order to explore possibilities for adaptation. The modeling approach considered a wide range of practices, including 50 crop rotations, two irrigation setups, three fertilization levels, and two soil managements, which allowed for exploring a wider range of options than in previous studies.

The geographic focus of the study was on western Switzerland. For this study area the following conclusions can be drawn:

- Under CC, we found a tendency for productivity to decrease, for erosion to increase due to shorter crop growth cycles and increased rainfall intensity in fall/ winter, and for N-leaching to increase as a consequence of higher mineralization rate.

- Productivity and soil loss due to erosion are highly variable not only with climate scenarios, but also across 
cropping practices and soil types, suggesting that negative impacts of $\mathrm{CC}$ can be reduced through an adequate choice of management.

- The relevance of agricultural practices as drivers of agricultural functions is not expected to change significantly with CC. Only irrigation is likely to become more important for agricultural productivity under $\mathrm{CC}$ scenarios that propose a marked decrease in water availability during summer.

- Trade-offs between agricultural productivity, soil erosion, and N-leaching are likely to aggravate with CC.

- There are possibilities to support multifunctional agricultural as some combinations of agricultural practices have beneficial effects both for productivity and for the environment. For the study region, the use of cropped grasslands in combination with conservation soil management appears to be the most suitable option to maintain productivity and avoid trade-offs with erosion and N-leaching.

Our work clearly shows that agricultural systems are complex and that trade-offs between different agricultural functions can emerge, which need to be taken into account when planning and implementing adaptation strategies.
As trade-offs can differ substantially depending on site conditions, spatial heterogeneities and characteristics need to be considered in the process of developing adaptation strategies at the regional scale. This has been shown in the context of catchment management (Marshall et al. 2010). Our study took a local view at the multifunctionality of agriculture under $\mathrm{CC}$. In the future the modeling framework developed for the present analysis will be integrated within a spatial multiobjective optimization routine to explore the multidimensional solution space in a systematic way and define regional adaptation options that are optimal with regard to the different agricultural functions.

Acknowlegments This study was supported by the Swiss National Science Foundation in framework of the National Research Program NRP61. We would like to thank MeteoSwiss for providing weather data. The ENSEMBLES data used in this work were funded by the EU FP6 Integrated Project ENSEMBLES (Contract number 505539) whose support is gratefully acknowledged. We are thankful to Raphael Charles who kindly double-checked the reliability of the generated crop rotations.

\section{Appendix}

See Tables 2, 3, 4, 5 and 6 .
Table 2 Changes in seasonal precipitation (\%), daily precipitation intensity index $(\%)$, and temperature $\left({ }^{\circ} \mathrm{C}\right)$ for two climate scenarios for 2050 (ETH-CLM and SMHIRCA-HadCM3Q3), relative to the baseline (1980-2009), for the A1B emission scenario (CH2011 2011); the daily precipitation intensity index is defined as the sum of daily precipitation amounts for wet days $(>1 \mathrm{~mm})$ divided by the number of wet days

\begin{tabular}{|c|c|c|c|c|c|c|}
\hline \multirow[t]{2}{*}{ Months } & \multicolumn{2}{|c|}{ Precipitation amount (\%) } & \multicolumn{2}{|c|}{ Precipitation intensity (\%) } & \multicolumn{2}{|c|}{ Temperature $\left({ }^{\circ} \mathrm{C}\right)$} \\
\hline & ETH & SMHI & ETH & SMHI & ETH & SMHI \\
\hline $\mathrm{M}-\mathrm{A}-\mathrm{M}$ & -14.18 & -1.35 & 3.27 & -3.2 & 2.22 & 0.98 \\
\hline $\mathrm{J}-\mathrm{J}-\mathrm{A}$ & -23.75 & -11.49 & 10.43 & -8.11 & 3.45 & 1.32 \\
\hline $\mathrm{S}-\mathrm{O}-\mathrm{N}$ & -1.76 & 20.73 & 8.83 & 3.61 & 2.44 & 1.24 \\
\hline D-J-F & -3.01 & 5.83 & 23.08 & 16.31 & 2.11 & 1.03 \\
\hline
\end{tabular}




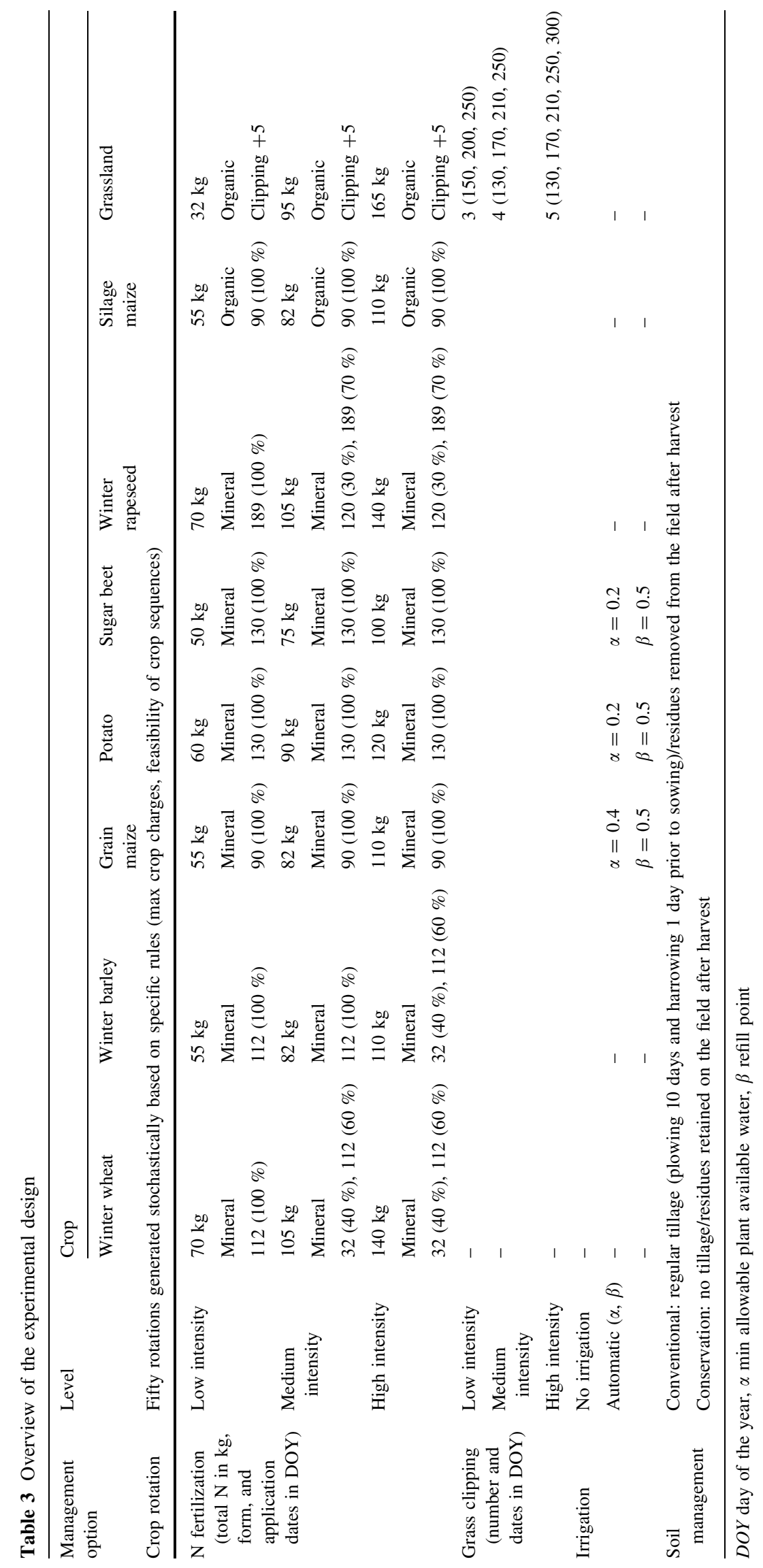


Table 4 List of the 50 crop rotations generated

\begin{tabular}{|c|c|c|c|c|}
\hline Year 1 & Year 2 & Year 3 & Year 4 & Year 5 \\
\hline Sugar beet & Silage maize & Winter barley & Grain maize & Winter wheat \\
\hline Winter barley & Potato & Grain maize & Winter wheat & Silage maize \\
\hline Sugar beet & Grassland & Grassland & Winter rapeseed & Winter barley \\
\hline Grain maize & Grassland & Grassland & Grain maize & Winter wheat \\
\hline Grassland & Grassland & Winter barley & Grain maize & Potato \\
\hline Winter wheat & Winter barley & Silage maize & Grassland & Grassland \\
\hline Potato & Grain maize & Winter wheat & Silage maize & Winter wheat \\
\hline Grain maize & Potato & Grassland & Grassland & Winter wheat \\
\hline Sugar beet & Grain maize & Winter wheat & Silage maize & Winter wheat \\
\hline Winter rapeseed & Grassland & Grassland & Winter wheat & Winter barley \\
\hline Winter wheat & Grassland & Grassland & Winter wheat & Silage maize \\
\hline Sugar beet & Grain maize & Grassland & Grassland & Winter wheat \\
\hline Silage maize & Grassland & Grassland & Grain maize & Potato \\
\hline Sugar beet & Winter wheat & Winter rapeseed & Potato & Winter wheat \\
\hline Winter wheat & Winter barley & Grassland & Grassland & Potato \\
\hline Winter rapeseed & Silage maize & Grassland & Grassland & Winter barley \\
\hline Sugar beet & Silage maize & Grassland & Grassland & Potato \\
\hline Sugar beet & Grain maize & Winter wheat & Winter barley & Potato \\
\hline Winter rapeseed & Grain maize & Winter wheat & Grain maize & Winter wheat \\
\hline Winter rapeseed & Potato & Silage maize & Winter wheat & Winter barley \\
\hline Sugar beet & Potato & Winter barley & Grassland & Grassland \\
\hline Winter barley & Grassland & Grassland & Winter barley & Potato \\
\hline Sugar beet & Grain maize & Winter wheat & Winter rapeseed & Winter wheat \\
\hline Winter rapeseed & Winter barley & Grassland & Grassland & Winter barley \\
\hline Silage maize & Winter barley & Silage maize & Grassland & Grassland \\
\hline Sugar beet & Grain maize & Potato & Grain maize & Winter wheat \\
\hline Winter rapeseed & Grain maize & Grassland & Grassland & Winter wheat \\
\hline Sugar beet & Winter wheat & Silage maize & Winter wheat & Potato \\
\hline Sugar beet & Winter wheat & Winter rapeseed & Winter barley & Potato \\
\hline Winter rapeseed & Winter wheat & Potato & Grain maize & Winter wheat \\
\hline Sugar beet & Winter wheat & Grassland & Grassland & Winter wheat \\
\hline Sugar beet & Grain maize & Grassland & Grassland & Winter barley \\
\hline Winter rapeseed & Grassland & Grassland & Sugar beet & Winter wheat \\
\hline Silage maize & Winter barley & Potato & Silage maize & Winter barley \\
\hline Grassland & Grassland & Winter barley & Silage maize & Winter barley \\
\hline Winter rapeseed & Silage maize & Potato & Silage maize & Winter barley \\
\hline Winter rapeseed & Grain maize & Potato & Sugar beet & Winter wheat \\
\hline Winter wheat & Grassland & Grassland & Winter wheat & Potato \\
\hline Winter rapeseed & Potato & Winter wheat & Grassland & Grassland \\
\hline Sugar beet & Grassland & Grassland & Potato & Winter wheat \\
\hline Winter rapeseed & Silage maize & Winter barley & Potato & Winter barley \\
\hline Sugar beet & Silage maize & Winter barley & Winter rapeseed & Winter barley \\
\hline Winter rapeseed & Potato & Grassland & Grassland & Winter barley \\
\hline Sugar beet & Silage maize & Winter barley & Silage maize & Winter barley \\
\hline Winter rapeseed & Winter wheat & Grassland & Grassland & Winter wheat \\
\hline Winter rapeseed & Silage maize & Potato & Grain maize & Winter wheat \\
\hline Winter rapeseed & Silage maize & Winter wheat & Silage maize & Winter barley \\
\hline Sugar beet & Grassland & Grassland & Winter wheat & Winter barley \\
\hline Winter rapeseed & Potato & Grain maize & Grassland & Grassland \\
\hline Winter rapeseed & Potato & Sugar beet & Grassland & Grassland \\
\hline
\end{tabular}


Table 5 Proportion of variance explained (main effects and interactions) by different agricultural practices on sandy loam soil

\begin{tabular}{|c|c|c|c|c|c|c|c|c|c|}
\hline & \multicolumn{3}{|c|}{ Productivity } & \multicolumn{3}{|l|}{ Erosion } & \multicolumn{3}{|c|}{ N-leaching } \\
\hline & Baseline & ETH & SMHI & Baseline & ETH & SMHI & Baseline & ETH & SMHI \\
\hline Crop rotation & $0.288^{\mathrm{a}}$ & $0.364^{\mathrm{a}}$ & $0.347^{\mathrm{a}}$ & $0.135^{\mathrm{a}}$ & $0.098^{\mathrm{a}}$ & $0.132^{\mathrm{a}}$ & $0.839^{\mathrm{a}}$ & $0.810^{\mathrm{a}}$ & $0.766^{\mathrm{a}}$ \\
\hline Irrigation level & $0.005^{\mathrm{a}}$ & $0.08^{\mathrm{a}}$ & $0.041^{\mathrm{a}}$ & $<0.001^{\mathrm{b}}$ & 0 & 0 & $0.021^{\mathrm{a}}$ & $0.052^{\mathrm{a}}$ & $0.049^{\mathrm{a}}$ \\
\hline Intensity & $0.346^{\mathrm{a}}$ & $0.273^{\mathrm{a}}$ & $0.325^{\mathrm{a}}$ & $0.029^{\mathrm{a}}$ & $0.03^{\mathrm{a}}$ & $0.041^{\mathrm{a}}$ & $0.041^{\mathrm{a}}$ & $0.029^{\mathrm{a}}$ & $0.031^{\mathrm{a}}$ \\
\hline Soil management & $0.261^{\mathrm{a}}$ & $0.152^{\mathrm{a}}$ & $0.172^{\mathrm{a}}$ & $0.731^{\mathrm{a}}$ & $0.771^{\mathrm{a}}$ & $0.716^{\mathrm{a}}$ & $0.043^{\mathrm{a}}$ & $0.046^{\mathrm{a}}$ & $0.078^{\mathrm{a}}$ \\
\hline Crop rotation: irrigation level & $0.003^{\mathrm{a}}$ & $0.028^{\mathrm{a}}$ & $0.015^{\mathrm{a}}$ & $0.001^{\mathrm{b}}$ & $0.001^{\mathrm{a}}$ & $0.001^{\mathrm{b}}$ & $0.019^{\mathrm{a}}$ & $0.034^{\mathrm{a}}$ & $0.036^{\mathrm{a}}$ \\
\hline Crop rotation: intensity & $0.017^{\mathrm{a}}$ & $0.031^{\mathrm{a}}$ & $0.036^{\mathrm{a}}$ & $0.006^{\mathrm{a}}$ & $0.008^{\mathrm{a}}$ & $0.009^{\mathrm{a}}$ & $0.012^{\mathrm{a}}$ & $0.007^{\mathrm{a}}$ & $0.010^{\mathrm{a}}$ \\
\hline Crop rotation: soil management & $0.076^{\mathrm{a}}$ & $0.058^{\mathrm{a}}$ & $0.055^{\mathrm{a}}$ & $0.094^{\mathrm{a}}$ & $0.088^{\mathrm{a}}$ & $0.096^{\mathrm{a}}$ & $0.022^{\mathrm{a}}$ & $0.017^{\mathrm{a}}$ & $0.025^{\mathrm{a}}$ \\
\hline Irrigation level: intensity & $0.001^{\mathrm{a}}$ & $0.003^{\mathrm{a}}$ & $0.002^{\mathrm{a}}$ & 0 & $<0.001^{\mathrm{c}}$ & 0 & $<0.001^{\mathrm{a}}$ & $0.001^{\mathrm{a}}$ & $0.001^{\mathrm{a}}$ \\
\hline Irrigation level: soil management & $0.002^{\mathrm{a}}$ & $0.006^{\mathrm{a}}$ & $0.006^{\mathrm{a}}$ & 0 & $0.001^{\mathrm{a}}$ & $<0.001^{\mathrm{a}}$ & $0.001^{\mathrm{a}}$ & $0.002^{\mathrm{a}}$ & $0.002^{\mathrm{a}}$ \\
\hline Intensity: soil management & $0.001^{\mathrm{a}}$ & $0.004^{\mathrm{a}}$ & $0.001^{\mathrm{a}}$ & $0.004^{\mathrm{a}}$ & $0.002^{\mathrm{a}}$ & $0.004^{\mathrm{a}}$ & $<0.001^{\mathrm{a}}$ & $0.001^{\mathrm{a}}$ & $0.001^{\mathrm{a}}$ \\
\hline
\end{tabular}

Significancy codes: $0>=\mathrm{a}<0.001>=\mathrm{b}<0.01>=\mathrm{c}<0.05$

Table 6 Proportion of variance explained (main effects and interactions) by different agricultural practices on loamy soil

\begin{tabular}{|c|c|c|c|c|c|c|c|c|c|}
\hline & \multicolumn{3}{|c|}{ Productivity } & \multicolumn{3}{|l|}{ Erosion } & \multicolumn{3}{|c|}{ N-leaching } \\
\hline & Baseline & ETH & SMHI & Baseline & ETH & SMHI & Baseline & ETH & SMHI \\
\hline Crop rotation & $0.343^{\mathrm{a}}$ & $0.387^{\mathrm{a}}$ & $0.405^{\mathrm{a}}$ & $0.133^{\mathrm{a}}$ & $0.092^{\mathrm{a}}$ & $0.135^{\mathrm{a}}$ & $0.904^{\mathrm{a}}$ & $0.870^{\mathrm{a}}$ & $0.908^{\mathrm{a}}$ \\
\hline Irrigation level & $0.001^{\mathrm{a}}$ & $0.038^{\mathrm{a}}$ & $0.014^{\mathrm{a}}$ & 0 & $0.001^{\mathrm{a}}$ & $0.001^{\mathrm{a}}$ & $0.005^{\mathrm{a}}$ & $0.02^{\mathrm{a}}$ & $0.02^{\mathrm{a}}$ \\
\hline Intensity & $0.322^{\mathrm{a}}$ & $0.266^{\mathrm{a}}$ & $0.306^{\mathrm{a}}$ & $0.033^{\mathrm{a}}$ & $0.034^{\mathrm{a}}$ & $0.045^{\mathrm{a}}$ & $0.008^{\mathrm{a}}$ & $0.009^{\mathrm{a}}$ & $0.012^{\mathrm{a}}$ \\
\hline Soil management & $0.239^{\mathrm{a}}$ & $0.157^{\mathrm{a}}$ & $0.158^{\mathrm{a}}$ & $0.733^{\mathrm{a}}$ & $0.773^{\mathrm{a}}$ & $0.711^{\mathrm{a}}$ & $0.042^{\mathrm{a}}$ & $0.053^{\mathrm{a}}$ & $0.013^{\mathrm{a}}$ \\
\hline Crop rotation: irrigation level & $0.001^{\mathrm{a}}$ & $0.016^{\mathrm{a}}$ & $0.007^{\mathrm{a}}$ & 0.001 & $0.002^{\mathrm{a}}$ & $0.002^{\mathrm{b}}$ & $0.015^{\mathrm{a}}$ & $0.023^{\mathrm{a}}$ & $0.026^{\mathrm{a}}$ \\
\hline Crop rotation: intensity & $0.018^{\mathrm{a}}$ & $0.041^{\mathrm{a}}$ & $0.041^{\mathrm{a}}$ & $0.006^{\mathrm{a}}$ & $0.009^{\mathrm{a}}$ & $0.010^{\mathrm{a}}$ & $0.006^{\mathrm{a}}$ & $0.006^{\mathrm{a}}$ & $0.010^{\mathrm{a}}$ \\
\hline Crop rotation: soil management & $0.073^{\mathrm{a}}$ & $0.083^{\mathrm{a}}$ & $0.062^{\mathrm{a}}$ & $0.090^{\mathrm{a}}$ & $0.084^{\mathrm{a}}$ & $0.091^{\mathrm{a}}$ & $0.019^{\mathrm{a}}$ & $0.018^{\mathrm{a}}$ & $0.011^{\mathrm{a}}$ \\
\hline Irrigation level: intensity & $<0.001^{\mathrm{a}}$ & $0.002^{\mathrm{a}}$ & $0.002^{\mathrm{a}}$ & 0 & $<0.001^{\mathrm{a}}$ & $<0.001^{\mathrm{b}}$ & 0 & $<0.001^{\mathrm{a}}$ & $<0.001^{\mathrm{a}}$ \\
\hline Irrigation level: soil management & $0.001^{\mathrm{a}}$ & $0.003^{\mathrm{a}}$ & $0.003^{\mathrm{a}}$ & 0 & $0.002^{\mathrm{a}}$ & $0.001^{\mathrm{a}}$ & $<0.001^{\mathrm{a}}$ & 0 & $<0.001^{\mathrm{c}}$ \\
\hline Intensity: soil management & $0.001^{\mathrm{a}}$ & $0.005^{\mathrm{a}}$ & $0.002^{\mathrm{a}}$ & $0.004^{\mathrm{a}}$ & $0.003^{\mathrm{a}}$ & $0.004^{\mathrm{a}}$ & $0.001^{\mathrm{a}}$ & 0 & $<0.001^{\mathrm{b}}$ \\
\hline
\end{tabular}

Significancy codes: $0>=\mathrm{a}<0.001>=\mathrm{b}<0.01>=\mathrm{c}<0.05$

\section{References}

Ammann C, Spirig C, Leifeld J, Neftel A (2009) Assessment of the nitrogen and carbon budget of two managed temperate grassland fields. Agric Ecosyst Environ 133(3-4):150-162

Arnold J, Williams J (1989) Stochastic generation of internal storm structure at a point. Trans ASAE 32(1):161-166

Askegaard M, Olesen J, Rasmussen I, Kristensen K (2011) Nitrate leaching from organic arable crop rotations is mostly determined by autumn field management. Agric Ecosyst Environ 142(3-4): $149-160$

Bachinger J, Zander P (2007) ROTOR, a tool for generating and evaluating crop rotations for organic farming systems. Eur $\mathbf{J}$ Agron 26(2):130-143

Bartsch KP, Miegroet HV, Boettinger J, Dobrowolski JP (2002) Using empirical erosion models and GIS to determine erosion risk at Camp Williams, Utah. J Soil Water Conserv 57(1):29-37

BFS (2004) Arealstatistik der Schweiz, Bundesamt für Statistik. SwiBFS, Neuchatel

BFS (2012) Soil suitability map of switzerland. GEOSTAT, CH-2010 Neuchatel, Switzerland

Bindi M, Olesen J (2010) The responses of agriculture in Europe to climate change. Reg Environ Chang 11(S1):151-158
BUWAL (2003) Nationales Bodenbeobachtungsnetz: Messresultate 1985-1991 (National soil observation network: results 1985-1991). Schriftenreihe Umwelt Nr. 200. Bundesamt für Umwelt, Wald und Landschaft (Hrsg.), CH-3003 Bern. 134 S., Anhnge $175 \mathrm{~S}$

Calanca P (2007) Climate change and drought occurrence in the Alpine region: how severe are becoming the extremes? Glob Planet Chang 57(1-2):151-160

CH2011 (2011) Swiss climate change scenarios CH2011. C2SM, MeteoSwiss, Zurich, p 88

Challinor A, Wheeler T, Garforth C, Craufurd P, Kassam A (2007) Assessing the vulnerability of food crop systems in Africa to climate change. Clim Chang 83(3):381-399

Confalonieri R (2010) Monte Carlo based sensitivity analysis of two crop simulators and considerations on model balance. Eur $\mathrm{J}$ Agron 33(2):89-93

Constantin J, Beaudoin N, Launay M, Duval J, Mary B (2012) Longterm nitrogen dynamics in various catch crop scenarios: test and simulations with STICS model in a temperate climate. Agric Ecosyst Environ 147:36-46

Corwin D, Waggoner B, Rhoades J (1991) A functional model of solute transport that accounts for bypass. J Environ Qual 20:647-658 
Dogliotti S, Rossing W, van Ittersum M (2003) Rotat, a tool for systematically generating crop rotations. Eur J Agron 19(2):239-250

Doltra J, Laegdsmand M, Olesen J (2011) Cereal yield and quality as affected by nitrogen availability in organic and conventional arable crop rotations: a combined modeling and experimental approach. Eur J Agron 34(2):83-95

Dueri S, Calanca P, Fuhrer J (2007) Climate change affects farm nitrogen loss - a Swiss case study with a dynamic farm model. Agric Syst 93(1-3):191-214

Duvick DN (2005) The contribution of breeding to yield advances in maize (Zea mays L.), vol 86. Academic Press, San Diego, pp 83-145

Evans R (2002) An alternative way to assess water erosion of cultivated land field-based measurements: and analysis of some results. Appl Geogr 22(2):187-207

Flisch R, Sinaj S, Charles R, Richner W (2009) GRUDAF 2009. Principles for fertilisation in arable and fodder production. Agrarforschung 16(2):1-100 (in German)

FOEN (2012) Adaptation to climate change in Switzerland. Goals, challenges and fields of action. First part of the Federal Councils strategy. Technical report, adopted on 2 Mar 2012. Edited by the Federal Office for the Environment

Fuhrer J, Jasper K (2012) Demand and supply of water for agriculture: influence of topography and climate in pre-alpine, meso-scale catchments. Nat Resour 3:145-155

Fuhrer J, Beniston M, Fischlin A, Frei C, Goyette S, Jasper K, Pfister C (2006) Climate risks and their impact on agriculture and forests in Switzerland. Clim Chang 79(1-2):79-102

Ginot V, Gaba S, Beaudouin R, Aries F, Monod H (2006) Combined use of local and ANOVA-based global sensitivity analyses for the investigation of a stochastic dynamic model: application to the case study of an individual-based model of a fish population. Ecol Model 193(3-4):479-491

Gobin A, Jones R, Kirkby M, Campling P, Govers G, Kosmas C, Gentile A (2004) Indicators for pan-European assessment and monitoring of soil erosion by water. Environ Sci Policy $7(1): 25-38$

Groot J, Rossing W, Jellema A, Stobbelaar D, Renting H, Van Ittersum M (2007) Exploring multi-scale trade-offs between nature conservation, agricultural profits and landscape qualitya methodology to support discussions on land-use perspectives. Agric Ecosyst Environ 120(1):58-69

Henke J, Böttcher U, Neukam D, Sieling K, Kage H (2008) Evaluation of different agronomic strategies to reduce nitrate leaching after winter oilseed rape (Brassica napus L.) using a simulation model. Nutr Cycl Agroecosyst 82(3):299-314

Horie T (1994) Crop ontogeny and development. In: Boote K, Bennett J, Sinclair T, Paulson G (eds) Physiology and determination of crop yield. ASA, Madison, pp 153-180

IPCC (2007) IPCC 2007: climate change 2007: impacts, adaptation and vulnerability. In: Parry ML, Canziani O, Palutikof J, van der Linden P, Hanson C (eds) Contribution of working group II to the fourth assessment report of the intergovernmental panel on climate change. Cambridge University Press, UK

Janssen S, Oomen R, Hengsdijk H, Van Ittersum M (2009) Agricultural management module of FSSIM, production enterprice generator, production technique generator, simple management translator and technical coefficient generator. SEAMLESS Report No.44, SEAMLESS integrated project. In: EU 6th framework programme, con. tech. rep.

Jones R, Bissonnais Y, Diaz J, Düwel O, Oygarden L, Bazzoffi P, Prasuhn V, Yordanov Y, Strauss P, Rydell B, Uveges J, Loj G, Vandekerckhove M (2003) Work package 2: nature and extend of soil erosion in Europe-interim report 3.31. EU soil thematic strategy. Technical Working Group on Erosion-European Commission-GD Environment, Brussels
Klein T, Calanca P, Holzkämper A, Lehmann N, Roesch A, Fuhrer J (2012) Using farm accountancy data to calibrate a crop model for climate impact studies. Agric Syst 111:23-33

Ko J, Ahuja L, Saseendran S, Green T, Ma L, Nielsen D, Walthall C (2011) Climate change impacts on dryland cropping systems in the Central Great Plains, USA. Clim Chang 111(2):445-472

Körner C, Morgan J, Norby R (2007) $\mathrm{CO}_{2}$ fertilization: when, where, how much? In: Canadell JG, Pataki DE, Pitelka LF (eds) Terrestrial ecosystems in a changing world. Springer, Berlin, pp 9-21

Lal R, Delgado J, Groffman P, Millar N, Dell C, Rotz A (2011) Management to mitigate and adapt to climate change. J Soil Water Conserv 66(4):276-285

Lamboni M, Makowski D, Lehuger S, Gabrielle B, Monod H (2009) Multivariate global sensitivity analysis for dynamic crop models. Field Crops Res 113(3):312-320

Lehmann N, Finger R, Klein T, Calanca P, Walter A (2013) Adapting crop management practices to climate change: modeling optimal solutions at the field scale. Agric Syst 117:55-65

Leifeld J, Bassin S, Fuhrer J (2003) Carbon stocks and carbon sequestration potentials in agricultural soils in Switzerland. Schriftenreihe der FAL 44

Long S, Ainsworth E, Leakey A, Nösberger J, Ort D (2006) Food for thought: lower-than-expected crop yield stimulation with rising $\mathrm{CO}_{2}$ concentrations. Science 312(5782):1918-1921

Marshall K, Blackstock KL, Dunglinson J (2010) A contextual framework for understanding good practice in integrated catchment management. J Environ Plan Manag 53(1):63-89

Michael A, Schmidt J, Enke W, Deutschländer T, Malitz G (2005) Impact of expected increase in precipitation intensities on soil loss-results of comparative model simulations. CATENA 61(2-3):155-164

Monod H, Naud C, Makowski D (2006) Uncertainty and sensitivity analysis for crop models. In: Wallach D, Makowski D, Jones J (eds) Working with dynamic crop models, pp 55-100

Moriondo M, Bindi M, Kundzewicz Z, Szwed M, Chorynski A, Matczak P, Radziejewski M, McEvoy D, Wreford A (2010) Impact and adaptation opportunities for European agriculture in response to climatic change and variability. Mitig Adapt Strateg Glob Chang15(7):657-679

Nearing M, Pruski F, O’Neal M (2004) Expected climate change impacts on soil erosion rates: a review. J Soil Water Conserv 59(1):43-50

Nearing M, Jetten V, Baffaut C, Cerdan O, Couturier A, Hernandez M, Le Bissonnais Y, Nichols M, Nunes J, Renschler C, Souchère V, van Oost K (2005) Modeling response of soil erosion and runoff to changes in precipitation and cover. CATENA 61(2-3):131-154

Nelson E, Mendoza G, Regetz J, Polasky S, Tallis H, Cameron D, Chan K, Daily G, Goldstein J, Kareiva P, Lonsdorf E, Naidoo R, Ricketts T, Shaw M (2009) Modeling multiple ecosystem services, biodiversity conservation, commodity production, and tradeoffs at landscape scales. Front Ecol Environ7(1):4-11

Nievergelt J (2002) Nitrat und Fruchtfolgen 20 Jahre lang beobachtet. Agrarforschung 9:28-33

Olesen J, Bindi M (2002) Consequences of climate change for European agricultural productivity, land use and policy. Eur J Agron 16(4):239-262

Olesen J, Trnka M, Kersebaum K, Skjelvå g A, Seguin B, PeltonenSainio P, Rossi F, Kozyra J, Micale F (2011) Impacts and adaptation of European crop production systems to climate change. Eur J Agron 34(2):96-112

Parry M, Rosenzweig C, Iglesias A, Livermore M, Fischer G (2004) Effects of climate change on global food production under SRES emissions and socio-economic scenarios. Global Environ Chang 14(1):53-67 
Power A (2010) Ecosystem services and agriculture: tradeoffs and synergies. Philos Trans R Soc B 365(1554):2959-2971

Prasuhn V (2012) On-farm effects of tillage and crops on soil erosion measured over 10 years in Switzerland. Soil Tillage Res 120:137-146

Prasuhn V, Liniger HP, Hurni H, Friedli S (2007) Carte du risque d'érosion du sol en Suisse. Rev Suisse Agric 39(2):53-59

Prasuhn V, Liniger H, Gisler S, Herweg K, Candinas A, Clément JP (2013) A high-resolution soil erosion risk map of Switzerland as strategic policy support system. Land Use Policy 32:281-291

Renard K, Foster G, Weesies G, McCool D, Yoder D (1997) Predicting soil erosion by water: a guide to conservation planning with the revised universal soil loss equation (RUSLE). US Department of Agriculture, Agriculture Research Service. Agriculture handbook no. 703, p 384

Renting H, Rossing W, Groot J, Vander Ploeg J, Laurent C, Perraud D, Stobbelaar D, Van Ittersum M (2009) Exploring multifunctional agriculture. A review of conceptual approaches and prospects for an integrative transitional framework. J Environ Manag 90:112-123

Rossing W, Zander P, Josien E, Groot J, Meyer B, Knierim A (2007) Integrative modelling approaches for analysis of impact of multifunctional agriculture: a review for France, Germany and The Netherlands. Agric Ecosyst Environ 120:41-57

Rötter R, Carter T, Olesen J, Porter J (2011) Crop-climate models need an overhaul. Nat Clim Chang 1(4):175-177

Ruane A, Cecil LD, Horton R, Gordón R, McCollum R, Brown D, Killough B, Goldberg R, Greeley A, Rosenzweig C (2013) Climate change impact uncertainties for maize in Panama: farm information, climate projections, and yield sensitivities. Agric For Meteorol 170:132-145

Sacks W, Kucharik C (2011) Crop management and phenology trends in the US corn belt: impacts on yields, evapotranspiration and energy balance. Agric For Meteorol 151(7):882-894

Saltelli A, Ratto M, Andres T, Campolongo F, Cariboni J, Gatelli D, Saisana M, Tarantola S (2007) Global sensitivity analysis. The primer. Wiley, Ltd, Chichester

Scholz G, Quinton J, Strauss P (2008) Soil erosion from sugar beet in Central Europe in response to climate change induced seasonal precipitation variations. CATENA 72(1):91-105

Schönhart M, Schmid E, Schneider U (2011) CropRota-a crop rotation model to support integrated land use assessments. Eur J Agron 34(4):263-277

Schröter D, Cramer W, Leemans R, Prentice I, Araújo M, Arnell N, Bondeau A, Bugmann H, Carter T, Gracia C, de la Vega-Leinert A, Erhard M, Ewert F, Glendining M, House J, Kankaanpää S, Klein R, Lavorel S, Lindner M, Metzger M, Meyer J, Mitchell T, Reginster I, Rounsevell M, Sabaté S, Sitch S, Smith B, Smith J, Smith P, Sykes M, Thonicke K, Thuiller W, Tuck G, Zaehle S, Zierl B (2005) Ecosystem service supply and vulnerability to global change in Europe. Science 310(5752):1333-1337
Semenov M, Barrow E (1997) Use of a stochastic weather generator in the development of climate change scenarios. Clim Chang 35(4):397-414

Soussana JF, Graux AI, Tubiello F (2010) Improving the use of modelling for projections of climate change impacts on crops and pastures. J Exp Bot 61(8):2217-28

Stöckle C, Campbell GS (1989) Simulation of crop response to water and nitrogen: an example using spring wheat. Trans ASAE 32(1):66-74

Stöckle C, Martin S, Campbell G (1994) CropSyst, a cropping systems simulation model: water/nitrogen budgets and crop yield. Agric Syst 46(3):335-359

Supit I, Van Diepen C, de Wit A, Wolf J, Kabat P, Baruth B, Ludwig F (2012) Assessing climate change effects on European crop yields using the crop growth monitoring system and a weather generator. Agric For Meteorol 164:96-111

Torriani D, Calanca P, Schmid S, Beniston M, Fuhrer J (2007) Potential effects of changes in mean climate and climate variability on the yield of winter and spring crops in Switzerland. Clim Res 34(1):59-69

Trnka M, Olesen J, Kersebaum K, Skjelvå g A, Eitzinger J, Seguin B, Peltonen-Sainio P, Rötter R, Iglesias A, Orlandini S, Dubrovský M, Hlavinka P, Balek J, Eckersten H, Cloppet E, Calanca P, Gobin A, Vučetić V, Nejedlik P, Kumar S, Lalic B, Mestre A, Rossi F, Kozyra J, Alexandrov V, Semerádová D, Žalud Z (2011) Agroclimatic conditions in Europe under climate change. Glob Chang Biol 17(7):2298-2318

UNCED (1992) United Nations conference on environment and development. Agenda $21 \mathrm{~d}$ an action plan for the next century.Technical report. In: United Nations conference on environment and development, New York

van der Linden P, Mitchell J (eds) (2009) ENSEMBLES: climate change and its impacts: summary of research and results from the ENSEMBLES project. Met Office Hadley Centre, Exeter, p 160

Van Ittersum M, Howden S, Asseng S (2003) Sensitivity of productivity and deep drainage of wheat cropping systems in a Mediterranean environment to changes in $\mathrm{CO}_{2}$, temperature and precipitation. Agric Ecosyst Environ 97(1-3):255-273

Vullioud P (2005) Assolement et rotation des grandes cultures. Rev Suisse Agric 37(4):1-1

Weisskopf P, Zihlmann U, Walther U (2001) Einfluss der Bewirtschaftung auf die Stickstoffdynamik im Bodenwasser. Agrarforschung 9:348-353

White J, Hoogenboom G, Kimball BA, Wall GW (2011) Methodologies for simulating impacts of climate change on crop production. Field Crops Res 124(3):357-368

Yang D, Kanae S, Oki T, Koike T, Musiake K (2003) Global potential soil erosion with reference to land use and climate changes. Hydrol Process 17(14):2913-2928 